\title{
MANHAJ FIKIH ISLAM KULTURAL (Eksplorasi, Kritik, dan Rekonstruksi)
}

\author{
Miftahul Huda \\ IAIN Mataram \\ Jl. Pendidikan No. 35 Mataram NTB \\ Email: miftahulda@gmail.com
}

\begin{abstract}
Abstrak
Meskipun memancar dari sumber pokok yang sama, al-Quran dan Sunnah, pemikiran hukum Islam (Fiqh) terus berkembang hingga kini menjadi varian-varian yang amat beragam. Di antara faktor penting yang mendorong keragaman tersebut adalah perbedaan perspektif tentang kemungkinan disertakannya pertimbangan kontekstual dan masuknya elemen sosiokultur masyarakat dalam proses $i j t i h \bar{a} d$. Bagi mereka yang menyetujuinya, elemen-elemen kultural dapat berperan dalam substansiasi, moderasi, seleksi, adaptasi dan instrumentalisasi konsep teoretik dan implementasi hukum Islam dalam kehidupan masyarakat. Namun demikian suatu pekerjaan besar masih diperlukan untuk lebih mematangkan dan mengembangkan manhaj ini secara lebih komprehensif dan detail sekaligus merespons setiap keberatan dan kritik-kritik tajam yang dilontarkan oleh berbagai kalangan umat. Upaya tersebut mencakup revitalisasi visi sosio-moralnya yang utama, pengembangan konsep metodologi yang lebih komprehensif dan detail sekaligus mengintegrasikan ilmu pengetahuan dan sains modern ke dalam bangunan pemikiran metodologisnya.
\end{abstract}

\begin{abstract}
Although it spouts from the same main sources, Al-Quran and Sunnah, theoritical concepts of Islamic law (Fiqh) are constantly growing into various kinds. Among many important factors that force the diversity is the different perspectives among Islamic scholars concerning contextual consideration and the act of accomodating sociocultural elements in ijtihad(a try to find out solution) process. For those who approve it, such elements of cultural wisdom might play important roles in substantiation, moderation, selection, adaptation and instumentation of theoritical concepts and technical implementation of Islamic law in social life. Albeit, it still needs many efforts to develop and ripen such a method in more comprehesive and detail ways and also to respond to any objections and outspoken critics from the society. Such efforts also include revitalizing the moral and social vision, developing the methodology and integrating modern sciences into the main frame of Islamic thinking.
\end{abstract}

Kata kunci: fikih, manhaj, kultur, konteks

\section{A. Pendahuluan}

Istilah $\quad$ islam kultural $^{l}$

menggambarkan pola pemahaman dan penerapan ajaran Islam yang secara umum berbeda dari Islam Lieteral. Sebenarnya kedua tipe pemikiran tersebut berasal dari sumber yang sama, al-Quran dan Sunnah. Perbedaannya terletak pada pola apresiasi, 
dan penerapannya dalam kehidupan sọsial. Dengan istilah, argumentasi dan lingkup penerapan yang berbeda-beda, "rumpun" Islam kultural memiliki ciri umum yang sama, yakni kesediaan untuk memperhatikan konteks sosio-historis dan akomodasi unsur kearifan kultural tertentu yang berkembang sesudah periode pewahyuan ('ahd al-nuzül)'.

Dalam perkembangannya identitas kontekstual-kultural dalam pemahaman dan pengamalan ajaran Islam dapat dibedakan secara sistematis dalam tiga ranah: Pertama, metode berpikir (manhaj al-fikr) termasuk dalam pemahaman Fikih. Dalam memahami teks-teks keagamaan (al-nushūsh al-dīniyyah) tidak boleh berhenti pada makna-makna harfiâhnya melainkan harus berupaya menyelami lebih dalam lagi tujuan sosiomoral yang lebih substansial.

Kedua, strategi dalam memperjuangkan misi keislamannya. Kalangan Islam kultural tidak nenempuh cara-cara pendekatan ideologis-politis dengan langkah-langkah perubahan yang radikal, dan revolusioner, tetapi lebih memilih strategi yang moderat, gradual, dan akomodatif terhadap elemen kultur dan modal sosial (social capital) yang ada.Target utama yang hendak diraih bukan pada aspek tampilan lạhiriah, formalitas, dan simbol-simbol kebanggaan primordial melainkan lebih pada tujuantujuan etisnya yang lebih substansial.

Ketiga, simbol-simbol sosiologis. dalam kehidupan bermasyarakat seperti mode pakaian, makanan, bahasa pergaulan, dan sebagainya. Dalam hal ini mengenakan pakaian sarung batik lokal dalam shalat misalnya, tidak dipandang kurang mulia dibanding jubah dan sorban. Atau penggunaan bahasa lokal dalam percakapan sehari-hari tidak kurang mulianya dari pada Bahasa Arab, karena kesalehan tidak hanya dinilai dari tampilan lahiriah dan simbol-simbol primordial seperti itu, melainkan dari sisi kesalehan yang lebih substansial seperti istiqâmah dan kekhusyukan ibadah, kejujuran, empati, sikap hormat kepada orang lain, sopan santun, pengorbanan untuk sesama, keberanian memperjuangkan kebenaran, dạn nilai-nilai akhlàk mulia lainnya.

\section{B. Paradigma}

Elemen-elemen pemahaman yang bercorak kultural-kontekstual sebenarnya telah ada sejak dahhulu, bahkan sejak era sahabat Rasul, yang kemudian berkembang hingga kini dengan segenap varian dan pasang surutnya. Dari waktu ke waktu para ulama telah menyumbangkan pemikirannya masing-masing untuk semakin "mèmatangkan" dan menyempurnakan pola pemahaman tersebut.

Sebelum Rasulullah SAW wafat, kaum muslimin memang tidak memerlukan reférensi lain, untuk memahami ajaran Işlam, karena semuanya dapat ditanyakan langsung kepada beliau. Apalagi pada saat ity jumlah mereka belum terlalu besar dan willayah domisili mereka juga belum terpencar di berbagai negeri yang saling berjauhan. Namun setelah Rasulullah wafat, tampak jelas bahwa ternyata para sahabat Rasul sendiri punya pemahaman yang berbeda-beda tentang banyak hal meskipup sebelumnya mereka sama-sama pernah menyertai Rasulullah SAẈ dalam wakpu yang lama. $\mathrm{Di}$ lingkungan sosialnya yang baru, para sahabat tersebut hạrus menghadapi dan merespons banyak masalah sosial yang baru "berdasarkan pengertian dan persepsinya masing-masing mengenai ajaran Rasulullah SAW. ${ }^{3}$

Misalnya Khalifah Umar bin Khathab pernah memutuskan untuk tidak memberikan jatah hạrta zakat kepada para muallaf (warga masyarakat yang baru masuk Islam) padahal al-Qur'an ${ }^{4}$ secara eksplișit menyatakan hal itu. ${ }^{5}$ Beliau juga pernah memutuskạn tanah-tanah di wilayah musuh yang berhasil dikalahkan dan menjadi pampasạ̉n perang (ghanimah) tetap dikelola oleh penduduk lokal (pemilik semula) tanpa mengharuskan męreka masuk Islạm terlebih dahulu. 
Padahal dalam pernyataan literal al-Quran dan praktek yang berlaku sejak jaman rasul tanah-tanah tersebut dibagikan kepada pasukan yang ikut dalam ekspedisi dan sebagian menjadi milik negara. Kebijakan lainnya adalah keputusan untuk tidak melaksanakan hukuman bagi pencuri sekalipun dalam al-Quran ${ }^{6}$ secara eksplisit terdapat perintah melaksanakan hukuman itu.

Kebijakan khalifah Umar tersebut memancing protes termasuk dari sejumlah sahabat Rasul yang terkemuka. Dalam pandangan mereka Khalifah Umar telah membuat keputusan yang keliru karena menyalahi "ajaran" Rasul. Namun khalifah Umar tetap bersikukuh dengan kebijakannya itu. ${ }^{7}$

Mengenai zakat, Khalifah Umar beralasan bahwa pemberian porsi zakat bagi para muallaf sebenarnya dimaksudkan untuk mengokohkan fondasi sosiopolitik masyarakat Islam yang baru terbentuk di zaman Nabi dan memberikan dukungan moral bagi orang-orang baru tersebut agar tetap teguh dengan keimanannya. Pada masa kepemimpinan khalifah Umar, kondisi umat Islam sudah cukup kuat sehingga tidak diperlukan lagi kebijakan karitatif bagi mereka yang baru masuk Islam. Khalifah berpandangan bahwa iman adalah kepentingan, dan urusan pribadi masing-masing individu. Dalam masalah ghanimah, Khalifah Umar memutuskan tanah tersebut tetap dikelola pemilik semula agar penduduk yang penguasanya baru dikalahkan itu terikat secara moral dengan pusat pemerintahan di Madinah sehingga mereka bisa berfungsi sebagai perisai teritorial yang efektif jika sewaktuwaktu muncul ancaman, infiltrasi ataupun serangan musuh dari luar. Sedangkan tentara yang ada dapat dikonsentrasikan ke kawasan lain yang memerlukan. Sedangkan pada kasus hukum potong tangan, keputusan itu diambil ketika terjadi musibah kemarau panjang yang dampaknya sangat parah. Dalam suasana demikian, menurut Khalifah Umar, seseorang yang terpaksa mencuri sekedar untuk mempertahankan jiwanya tidak pantas dihukum potong tangan, karena langkah seperti itu akan melukai hati nurani dan rasa keadilan.

Terlepas dari setuju atau tidak setuju terhadap kebijakan Khalifah Umar tersebut, contoh-contoh yang telah disebutkan sudah cukup menunjukkan bahwa sekalipun para sahabat sama-sama pernah hidup bersama Rasul dalam waktu yang cukup lama, mendengar apa yang dikatakannya, melihat apa yang dilakukannya dan pada masa itu pula alQuran diwahyukan, namun mereka tetap banyak berbeda pendapat mengenai apa yang sesungguhnya dikehendaki oleh Rasul dalam banyak sekali "teks" katakata dan tindakannya. Dalam contoh di atas tampak bahwa Khalifah Umar memahami ayat al-Quran dengan fokus perhatian (angle) yang berbeda dari sahabat yag lain karena beliau lebih menonjolkan aspek "spirit" sosiomoral dari suatu nash dan bukan pada makna harfiahnya. ${ }^{8} \quad$ Karena jika ayat tersebut diterapkan menurut makna harfiahnya, justru akan lebih banyak merugikan nilainilai etika syariat yang lebih substansial, seperti rasa keadilan, empati, dan ikhtiar meningkatkan kesejahteraan umat.

Dari sisi metode berpikir (manhaj alfikr), pemahaman Islam yang bercorak kultural-kontekstual didasarkan pada sejumlah paradigma sebagai berikut:

Pertama, karakteristik misi risālah Muhammad SAW sebagai rahmat bagi semua $^{9}$ harus dipertahankan dan dilanjutkan oleh umat Islam sepeninggal beliau. Misi mulia tersebut harus terusmenerus diwujudkan di pentas sejarah dengan cara-cara yang konkret, mulia, dan beradab. Nilai-nilai moral fundamental seperti kekhusyukan dalam ritual, ${ }^{10}$ kesucian jiwa, ${ }^{11}$ ketabahan saat mengalami ujian, ${ }^{12}$ keadilan, ${ }^{13}$ kejujuran, ${ }^{14}$ persaudaraan $^{15}$, solidaritas sosial, dan empati ${ }^{16}$ harus senantiasa dijunjung tinggi. $^{17}$

Kedua, setiap lingkungan masyarakat memiliki nilai-nilai luhur, dan kearifan 
kultural yang perlu dilestarikan. Kedatangan Islam bukan untuk merombak total semua yang ada sebelumnya melainkan untuk meningkatkan dan menyempurnakan hal-hal yang sudah baik serta mengoreksi bagian-bagian tertentu yang dipandang masih keliru. Dengan menjaga keseimbangan antara perspektif perubahan dan kesinambungan (change and continuity), maka ikhtiar membumikan ajaran Islam diharapkan akan berproses secara damai, beradab, dan berkelanjutan sejalan dengan denyut perkembangan sosial.

Ketiga, inti ajaran Islam adalah 'aqijdah dan $a k h l a \bar{q}$, yang kemudian diimplementasikan lewat penerapan syarïah. Dengan kata lain, syari'ah sesungguhnya merupakan "instrumen" untuk menegakkan "aqĩdah dan akhläq yang Islami secara komprehensif. Semua konsep pemikiran syariah, strategi dan langkah-langkah penerapannya harus didesain sesuai dengan spirit dan landasan fundamentalnya, yakni 'aqidah dan akhlāq. Oleh karena itu semua paham dan cara-cara memperjuangkan Islam yang bertentangan dengan kemuliaan martabat kemanusiaan harus senantiasa dihindari, misalnya dakwah dan perjuangan menegakkan syariat lewat caci maki, pemaksaan, intimidasi, tindak kekerasan, dan perusakan.

Keempat, meskipun Islam memiliki visi transformasi sosiomoral yang berwawasan jauh ke depan, perjuangan membumikannya memerlukan langkahlangkah yang bijaksana, sesuai dengan situasi dan tahapan kesiapan sosiologis masyarakat. Perbedaan situasi, modal sosial, dan keragaman kultur yang selalu ada di mana-mana harus dipertimbangkan dengan sebaik-baiknya agar implementasi syariah dapat mencapai tujuannya secara damai dan bermartabat. Melalui kajian sistematis atas nilai-nilai syariat yang utama, seharusnya diidentifikasi secara sistematis aturan syariat yang sebaiknya diimplementasikan melalui pendidikan, ceramah, kontak-kontak personal, pemberdayaan sosial, media informasi, dan perjuangan politik (legal policy).

Dalam hal ini modifikasi instrumen teknis dalam kemasan konseptual, dan terminologi yang berkembang dalam kehidupan masyarakat juga tidak harus dipersoalkan karẹna yang lebih penting adạlah terwujudnya nilai-nilai noral fundamentalnya. Misalnya penggunaan istilah "demokrasi", "good governance", "ekonomi kerakyatan", dan sebagainya tidak harus diganti seluruhnya dengan istilah-istilah berbahasa Arab, sepanjang substansinya sesuai dengan nilai--nilai moral syariat. Demikian pula berbagai modal sosial (social capital) yang sudah ada juga tidak hạnus diganti semuanya dengan yang baru jseperti tatanan politik, tradisi, kultur, dạn institusi sosial yang sudah ada.

Jika didasarkan pada paradigma tersëbut, maka tekș-teks syariat tidak harus selalu dipahami dan diaplikasikan menurut makna harfiahnya di semua tempat, waktu dan situasi. Teks-tekks syariat secara garis besar diklasifikasi menjadi dua kategori:

Pertama teks-teks syariat yang menjelaskan prinsip-prinsip aqïdah dan moral .Islam yang universal. Kandungan teks-teks seperti: ini memiliki nilai kebenaran yang bersifat absolut, final dan abadi, sehingga ḅerlaḳu dalam semua tempat, waktu, dan situasi. Berbagai peraturan terkait , upacara ritual pada umumnya juga dikelompokkan di sini sekalipun tidak seluruhnya.

Kedua, teks-teks yang berisi ketentuan yang sifatnya teknis dan instrumental. Pada ranah implementasinya, teks-teks seperti ini dipahami sebagai alternatif di antara !pilihan-pilihan lainnya yang dapat ditemúkan dan dipilih secara rasional. Atau juga poisa dipandang sebagai tahapan dari proses pembumian nilai-nilai akidah dan moral syariat yang universal sesuai dengan kesiapan sosiologis masyarakat pada saat itu. Oleh karena itu, sejumlah modifikasi teknis dalam batas tertentu atau "penundaan":aplikasinya dalam jangka wakgtu tertentu mungkin 
diperlukan sesuai dengan relevansinya dengan situasi dan kesiapan sosilogis masyarakat.

Penting untuk digarisbawahi bahwa manhaj ini tidaklah menolak sama sekali makna literal teks syariah dalam semua ketentuan hukum yang bersifat teknis. Jika dari pertimbangan konteks 'sosiokultur ternyata makna literal memang menjadi pilihan "terbaik" untuk mencapai tujuantujuan fundamentalnya, maka ketentuan teknis yang dijelaskan secara literal tersebut yang harus dipilih dan diimplementasikan.

\section{Metode Istinbāt dalam Fikih}

Bagi kaum muslimin, al-Quran dan Hadits merupakan rujukan pokok dalam memahami ajaran Islam, termasuk juga dalam bidang hukum (Fikih). Namun demikian penting untuk digarisbawahi bahwa status al-Quran dan Hadits adalah "sumber hukum" dan bukan hukum itu sendiri, sehingga untuk memahami konsep hukumnya (Fikih) masih diperlukan telaah mendalam dari berbagai sisi agar dapat diperoleh pemahaman yang tepat. Dalam hal ini, para ulama menggunakan rujukan lainnya yang sifanya sekunder dan metodologis menurut versinya masingmasing seperti Ijmā', Qiyās, maslahah, dan sebagainya.

Sebagai rumusan konkret dari aplikasi nilai-nilai syariat dalam kehidupan masyarakat, Fikih tidak lepas dari pengaruh perubahan zaman dan perkembangan situasi. $^{18} \quad$ Norma keagamaan tersebut disimpulkan para ulama melalui proses ijtihād dari sumbersumber keagamaan (al-masādir aldiniyyah) yang secara tekstual sering berbeda satu sama lain. Dari gugusan informasi yang saling berbeda itu, kemudian ditarik rumusan norma-norma hidup dengan menggunakan metodologi, pendekatan dan kaidah penafsiran ( tarīqah al-istinbāt) tertentu. ${ }^{19}$

Penalaran (istinbāt) hukum diawali dengan menggali, merumuskan secara sistematis prinsip-prinsip 'aqīdah dan akhlāq Islam yang fundamental sebagai dasar pijak dalam menangani semua masalah hukum. Dari sisi 'aqīdah, setiap konsep Fikih harus bertolak dari prinsip memelihara kemurnian tawhīd yang dalam batas tertentu bersifat "eksklusif". 20 Prinsip tawhīd juga mengandung pesan untuk selalu mengikuti ketentuan yang ditetapkan oleh Allah SWT. ${ }^{21}$, tanggung jawab moral untuk melindungi diri sendiri, dan keluarga dari kesesatan ${ }^{22}$ serta pesan untuk menemukan sarana yang diperlukan untuk meingkatkan taqwā kepada Allah SWT. $^{23}$

Sedangkan dari sisi akhlāq, pengembangan Fikih harus selalu bertolak dari spirit pengabdian ("ibädah) yang tulus kepada Allah SWT yang merupakan puncak dari semua sumber nilai kebenaran, serta penghargaan terhadap kemuliaan martabat kemanusiaan dengan memperhatikan nilai-nilai fundamentalnya seperti kekhusyukan dalam ritual, ${ }^{24}$ kesucian jiwa, ${ }^{25}$ ketabahan saat mengalami ujian, ${ }^{26}$ keadilan sosial, ${ }^{27}$ kejujuran, ${ }^{28}$ persaudaraan $^{29}$, empati dan solidaritas sosial. $^{30}$

Hal itu berarti, sekalipun dalam ketentuan yang lebih detail bisa melahirkan konsep Fikih yang beragam, namun keseluruhan konsep tersebut harus selalu bertolak dari argumentasi, spirit dan prinsip umum 'aqīdah dan akhlāq yang islami. Konsep-konsep Fikih harus senantiasa dirancang untuk mendorong proses transformasi sosial guna mewujudkan nilai-nilai fundamental tawhìd dan akhlāq dalam kehidupan sosial, baik yang menyentuh bidang tertentu seperti ekonomi, dan politik, maupun dalam kehidupan sosial secara keseluruhan. Semua konsep Fikih yang jelas bertentangan dengan arah spirit tawhìd dan akhlāq tidak dapat dibenarkan, sekalipun dari sudut pandang tertentu mungkin memiliki argumentasi dan nilai manfaat bagi kepentingan hidup manusia.

Dalam merespons kasus-kasus yang konkret (al-masā'il al-wāqi'iyyah) langkah penanganannya adalah sebagai berikut: 
Pertama, mengidentifikasi , rujukanrujukan literal yang sahih dalam dua sumber utama yakni al-Quran dan Hadits, beserta informasi mengenai latar sosiohistoris munculnya teks-teks tersebut (asbāb al-nuzūl dalam maknanya yang luas). ${ }^{31}$ Melalui analisis atas makna literal teks-teks syariat tersebut, beserța latar sosio-historisnya, kemudian diidentifikasi masalah sosial yang direspons teks-teks tersebut, bentuk-bentuk responsnya secara konkret serta arah visi sosiomoralnya.

Kedua, mengidentifikasi berbagai alternatif konsep pemikiran hukum yang relevan dengan masalah yang sedang dikaji. Alternatif tersebut dapat ditemukan langsung dari makna literal al-Quran dan Hadits, pendapat para ulama, pengalaman historis kaum muslimin, analisis rasional atau petunjuk sains.

Ketiga, melakukan kajian kontekstual terhadap situasi, tantangan, dan permasalahan aktual yang dihadapi masyarakat baik di masa sekarang maupun di masa yang akan datang.

Keempat, berbekal semua hasil analisis tersebut kemudian dilpilih salah satu di antara alternatif pemikiran yang dinilai paling cocok dan paling efektif dalam memecahkan masalah sosial yang ada, baik di masa sekarang maupun di masa depan, demi terwujudnya seoptimal mungkin tujuan-tujuan moral findamentalnya (maqāsid al-syari'ah al'ämmah).

Melalui prosedur analisis sosiohistoris atas teks syariat di era pewahyuan ('ahd al-nuzūl) serta pertimbangan kontekstual saat pesan teks tersebut hendak diimplementasikan di era kontemporer, maka kesimpulan akhir yang diperoleh akan terbuka kemungkinan sebagai berikut:

a. Pengertian yang digunakan identik dengan makna literalnya.

b. Pengertian yang digunakan lebih luas dari makna literalnya

c. Pengertian yang digunakan lebih sempit dari makna literalnya d. Suatu teks dinilai tidak memiliki signifikantsi karena memang tidak terkait dengan masalah yang ada atau karẹna ada "teks" lain yang dipandang lebih "tepat" untuk

$\ldots$ menangahi suatu masalah.

\section{Apresiasi dan $\cdot$ Kritik}

Dari waktu ke waktu, pola pemikiran Fikih yang bercorak kontekstual-kultural telah.menarik perhatian banyak ulama dan ahli hukum, (Fuqahā), untuk mengembangkannya menurut versinya masing-masing. Hall itu antara lain karena:

Pertama, pola pikir kontekstualkultural dinilai lebih mampu merespons dan menangani masalah sosial yang terus berkembang. Karena jika semua teks syariat (al-nusūs 'ál-syar'iyyah) dipahami dan diaplikasikan sebatas makna literalnya, maka teks literal yang jumlahnya terbatas tidak akan dapat menampung dan menrespons semua masalah dalam kehidüpan manusià yang jumlahnya tidak térbatas dan terus berkembang baik secara kuantitatif maupun kualitatif. Seperti ditunjukkan Hassan Hanafi, pemikiran keagamaan yang'bertumpu pada model "upaya pengälihan' teks ke dalam realitas sosial" mengandung banyak kelemahan yang amat mendasar ${ }^{32}$

Kedua, pedekatan kontekstualkultural dinilai lebih bisa merespons dan menangani masaldh secara konkret dan akuntabel, karena konsep-konsep hukum disusur dan " diimplementasikan berdasarkan pertimbangan situasi yang kónkret, bukan h̆anya atas argumentasi ideologis dan teologis. Secara sosiologis, pengembangan 'kónsep dan penerapan aturan hukum memang seharusnya memperhiturigkan secara cermat implikasi dari p̉enerapan aturan hukum tersebut, agar implementasi aturạn hukum syariat benarbenar bisa membéri solusi konkret atas masalah-masalah yang dihadapi umat dan bukan malah : memperumit atau menimbulkan masalah-masalah baru. ${ }^{33}$

Ketiga, den̈gan pola pemikiran kontekstual-kultural kaum muslimin dapat 
tetap melestarikan semua kekayaan kultural dan modal sosial (social capital) yang mereka miliki, bahkan memanfaatkannya untuk menunjang usaha membumikan nilai syariat. Perubahan dilakukan hanya jika dipastikan bahwa alternatif penggantinya memang lebih unggul dari berbagai sisi dibanding yang sudah ada. Dalam kajian hukum Islam hal ini dirumuskan dalam kaidah al-muhäfazah 'alā al-qadìm al-sālih wa al-akhz bi aljadìd al-aslah (tetap melestarikan unsurunsur lama yang baik, dan mengakomodasi unsur-unsur baru yang lebih baik). Dengan demikian proses aplikasi hukum Islam dalam kehidupan sosial dapat berjalan secara damai, sistemik dan berkelanjutan ${ }^{34}$

$$
\text { Keempat, pola pemikiran }
$$

kontekstual-kultural dinilai lebih mampu "berdialog" dengan dinamika kehidupan, rasionalitas dan alam pikiran masyarakat modern, seperti dalam masalah sosialpolitik, ekonomi maupun dengan perkembangan sains dan teknologi modern. Dengan pola pikir demikian kaum muslimin juga dapat berdampingan, dan bekerja sama dengan komunitas lain, serta merespons secara kritis-konstruktif terhadap berbagai permasalahan umat manusia, dari yang berskala lokal hingga global seperti isu-isu kemiskinan, keterbelakangan, demokrasi, negarabangsa (nation-state), ketimpangan jender, wabah penyakit, ketidakadilan dan lingkungan hidup (ekologi). ${ }^{35}$ Pola-pola pikir doktriner ideologis yang mengabaikan pertimbangan kontekstual kultural akan membuat Islam dan umat Islam terus-menerus berada dalam situasi ketegangan, konflik dan keterasingan dari dunia di sekitarnya.

Namun demikian, dari cara pandang yang berbeda, pola pemikiran kontekstualkultural juga mengundang sejumlah keberatan dan kritik-kritik tajam sebagai berikut:

Pertama, pola pikir kulturalkontekstual dapat memperluas peluang munculnya tafsir sewenang-wenang atas teks-teks syariat yang didasarkan pada selera dan dorongan hawa nafsu. Hal itu karena setiap teks, peristiwa dan situasi dapat dipahami secara berbeda-beda bergantung pada perspektif, pendekatan, motif dan kepentingan yang mendasarinya. Akibatnya pemikiran hukum Islam akan mengikuti selera para penafsir dengan segenap kelemahan, motif, dan kepentingannya sehingga dikhawatirkan syariat Islam akan hilang terbawa arus perkembangan zaman karena terusmenerus didekonstruksi oleh tafsir-tafsir baru yang terus bermunculan. Dalam sejarah pemikiran hukum Islam, kelemahan ini telah mendorong Ibnu Hazm (994-1064 M) beralih ke mazhab zāhiri dan tampil menjadi pembelanya yang gigih, setelah sebelumnya mengikuti mazhab Maliki dan mazhab Syafi'i.. ${ }^{36}$

Kedua, seiring perkembangan pemikiran umat Islam, sudah sejak lama arus utama dari pola pikir kontekstualkultural telah berkembang menjadi pola pikir literalis jenis baru dengan segenap kelemahannya. Pola-pikir baru tersebut tidak lagi bertumpu pada sumber-sumber otentik nash-nash syariat melainkan pada teks-teks sekunder hasil karya para tokoh ulama Fikih. Karya-karya intelektual yang pada mulainya merupakan wujud dari "kreativitas" dan produktivitas intelektual para ulama dalam merespons masalah sosial yang berkembang di masanya, pada akhirnya mengalami proses pembukuan, pembakuan dan pembekuan pada era-era generasi ulama sesudahnya. Melalui karya intelektual dan kiprah sosial masingmasing, para ulama generasi baru tersebut kemudian tampil membela dengan setia teks-teks sekunder tersebut seiring dengan menguatnya semangat taqlìd dan persaingan sektarian.. ${ }^{37}$ Sehingga pemikiran hukum Islam menjadi mandeg, sektarian, kurang berwawasan, serta kehilangan elan vital dan kekuatan spirit transformatifnya yang otentik.

Ketiga, pola pikir kontekstualkultural berpotensi mendorong terjadinya perpecahan sosial di kalangan umat karena perbedaan pendapat menjadi tidak 
terkendali. Tidak adanya kriteria yang jelas dan dipatuhi mengenai kualifikasi, orangorang yang boleh melakukan ijtihäd, mendorong munculnya mujtahid yang sesungguhnya belum memiliki kompetensi melakukan ijtihād, sekalipun memiliki keahlian pada bidang-bidang lain. Kondisi ini dapat semakin mencabik-cabik keutuhan umat menjadi kelompokkelompok kecil yang saling bersaing.

Keempat, terbukanya banyak kemungkinan terserapnya elemen-elemen kultur masyarakat yang berpotensi menjerumuskan umat dalam bahaya syirik dan unsur-unsur kebudayaan yang berpotensi mencemari kemurnian ajaran Islam. Hal itu karena kriteria dari elemen kultur yang bisa diakomodasi dalam bangunan pemikiran hukum Islam belum didefinisikan dengan tuntas, tegas, dan disepakati oleh semua komponen umat. ${ }^{38}$

\section{E. Rekonstruksi}

Dengan tetap mempertahankan kelebihan-kelebihan utamanya, pola pemikiran kultural kontekstual masih terus memerlukan sentuhan dan pengembangan lebih lanjut agar dapat mengatasi berbagai kekurangannya dan merespons berbagai kritik yang dilotarkan berbagai kalangan. Ikhtiar tersebut terutama menyangkut dua hal.

Pertama, merumuskan secara komprehensif visi sosiomoral hukum Islam, baik yang menyentuh aspek-aspek tertentu seperti politik, ekonomi, ekologi dan aspek kehidupan lainnya, maupun hukum Islam secara keseluruhan. Pola pengkajian dan pengembangan hukum Islam seharusnya tidak lagi längsung masuk ke aspek-aspek kehidupan yang sifatnya teknis lewat rujukan teks :syariat yang juga bersifat teknis seperti.-cara melakukan shalat, membasuh najis, susunan kalimat akad nikah, cara menghukum pezina dan sebagainya, melainkan berawal dari kajian sistematis mengenai prinsip-prinsip hukum Islam yang fundamental mengenai shalat, nikah dan pidana. Langkah ini diperlukan agar sejak awal konșep-konsep hukum Islam memiliki landasan filosofis yang kokoh dan agar pengembangan pemikiran hukum Islam. șelanjutnya tidak mengalami disoriêntasi sehịgga tetap berada pada arah yang benar (on the track). Penegasan visi tersebut | sekaligus untuk membangkitkan kembali semangat transformatifnya yang otentik.

Perlu ditegaskan bahwa pengembangan, manhaj hukum Islam harus bertolak dari prinsip kemurnian tawhīd dan teologi-moral Islam yang dalam batas tertetu bersifat "êksklusif". 39 Oleh karena itu, pengembangán konsep hukum tidak boleh hanya diḍasarkan pada konsensus "selera" di , antara sesama manusia (komunitas umat Islam) misalnya atas nama prinsip humanisme atau manfaat (mashlahah), melainkan harus tetap bertolak dari spintit pengabdian ('ibādah) kepada Allah SWWT yang merupakan puncak dari semua sumber nilai kebenaran. Demikian juga perhatian terhadap pesan moral untuk mélindungi diri sendiri, keluarga dari kesesatan, ${ }^{40}$ dan pesan untuk menemukan 'sarana-sarana untuk meningkạtkan taqjwā kepada Allah SWT. ${ }^{41}$ Prinsip tawhid tersebut juga memuat perintah yang jelass untuk hanya mengikuti ketentuan hukum! yang ditetapkan oleh Allab. ${ }^{42}$

Kedua, merumuskan secara lebih komprehensif, sistematis dan lebih detail metode. istinbath yang dapat mengidentifiḳasi đan menyeleksi elemen kultur yang boleh dan tidak boleh dimasukkan dalam bangunan pemikiran hukum Islam, serta untuk memberikan batasan yang jelas pada tingkat mana perubahan-perubahan konsep hukum bisa dilakukan berdasárkan interpretasi yang lebih tepat atas dua sumber utamanya yakni al-Quran dan Sunnah Rasul.

Agar konsep hukum lebih sesuai dengan kebutuhan!dan situasi aktual yang dịhadapi masyarakat, maka akomodasi atas, elemen kulutur tertentu menjadi kebutuhan yang penting, tanpa menganggapnya sẹbagai elemen luar yang 
mencemari ortodoksi dan kemurnian ajaran Islam. Elemen-elemen kekayaan kultural tersebut digunakan dalam hal-hal berikut:

a. Substansiasi, yaitu memahami tujuan sosio-moralnya yang substansial. Hal itu karena pemahaman dan penerapan nilai-nilai syariat tidak boleh hanya mementingkan formalitas dan simbol-simbol lahiriah melainkan harus berorentasi pada visi sosio-moral yang menyentuh berbagai sisi kehidupan umat. Dalam konteks ini khazanah kearifan kultural, baik yang tradisional maupun modern, akan dapat memberikan banyak inspirasi dan memperkaya perspektif dalam pemahaman pesan-pesan sosio-moral ajaran syariat yang suci. Misalnya pemaknaan kata ghārim dalam ayat zakat seharusnya tidak didasarkan secara kaku pada terjemah literalnya yakni (semua) orang-orang yang berhutang. ${ }^{43}$ Hal itu karena orangorang yang berhutang banyak variannya, ada hutang untuk kegiatan bisnis produktif, hutanng untuk keperluan konsumtif oleh mereka yang sesungguhnya memiliki penghasilna cukup dan hutang oleh mereka yang lemah karena termarginalkan dan "dimiskinkan" oleh sistem dan kultur yang cenderung menindas. Tanpa pemilahan sistematis seperti itu implementasi zakat akan salah sasaran sehingga tidak dapat mencapai tujuan fundamentalnya, yakni membantu mereka yang lemah dan dilemahkan oleh sistem dan kultur yang menindas mereka.

b. Moderasi, yakni pengembangan pola pemahaman keagamaan yang lebih moderat seiring dengan dinamika dan kompleksitas kehidupan masyarakat. Kekaguman dan keyakinan seseorang terhadap suatu pemikiran Fikih tertentu, ketika hendak dibawa dalam ranah kehidupan publik yang luas, seharusnya ditampilkan dengan penuh kerendahan hati disertai sikap penghargaan terhadap kebebasan orang lain untuk menentukan pilihannya. Implementasi semua aktivitas ibadah, jihād, dan dakwah, betatapun gigih dan semangatnya, harus tetap dilakukan dengan caracara yang bijaksana, santun, dan akhlak mulia. Misalnya dalam masyarakat yang damai tidak diperlukan kumandang dakwah "jihad keras" mengangkat senjata sekalipun dengan cara "dipilih-pilih" bisa dicari argumentasi teks keagamaan yang mendukungnya. Dalam masyarakat seperti itu yang diperlukan adalah "jihad lunak" lewat dunia pendidikan, politik, ekonomi, ekologi, seni budaya dan sebagainya untuk membantu umat mensejahterakan dirinya dan membangun peradaban masa depan yang lebih baik secara damai.

c. Seleksi dan adaptasi yakni penyaringan dan penyesuaian berbagai konsep Fikih sesuai dengan kondisi, dan kesiapan sosiologis di setiap lingkungan sosial. Proses seleksi terjadi karena konsep pemikiran Fikih, bagaimanapun bagusnya secara teoretik, tidak semuanya dapat diterapkan begitu saja secara serentak dan seragam di semua lingkungan sosial. Sehingga selalu harus ada skala prioritas sesuai dengan situasi di masing-masing lingkungan sosial. Modifikasi pada tingkat tertentu seringkali diperlukan karena perbedaan suasana kehidupan memerlukan respons teknis yang berbeda-beda pula, sepanjang modifikasi tersebut tidak meruntuhkan nilai-nilai fundamentalnya. Begitu pula "penundaan" implementasi aturan syariat pada aspek tertentu seringkali diperlukan untuk melakukan langkah-langkah persiapan dan memastikan bahwa umat memang telah siap menerapkan aturan tersebut. Pemikiran 
cemerlang Imam Syafi'i atau Ibnu Taymiyah misalnya, sekalipun dapat dikaji dengan luas dan mendalam dalam forum halaqah ulama, daurah komunitas harakah dan kuliah pascasarjana, namun secara sosiologis tidak akan dapat diterapkan sepenuhnya di semua lingkungan masyarakat karena di sana ada sistem politik, sistem hukum, sistem ekomomi, dan kultur yang bekerja secara otomatis untuk menyeleksi dan "memaksanya" untuk beradaptasi jika hendak diterapkan dalam kehidupan masyarakat.

d. Instrumentalisasi, yaitu pemanfaatan elemen-elemen kearifan lokal, kultur, tradisi, dan modal sosial (social capital) lainnya sebagai sarana, jalan, media, atau instrumen teknis dalam ikhtiar pembumian nilai-nilai, ajaran syariat. Di antara instrumen teknis tersebut ada yang terkait dengan tata cara pelaksanaan, waktu, tempat, dan peralatan yang dipergunakan.. Misalnya aktivitas zikir, doa, tilläwah al-Quran dan dakwah yang, waktu dan tempatnya tidak diațur ketat dalam aturan syariat, bisa dilaksanakan dengan memanfaatkan momen-momen sosial-budaya tertentu seperti hari ulang tahun kelahiran dan pernikahan, hari kemerdekaan suatu negara, dan momen-momen acara adat, lokal tertentu sepanjang tidak disertai halhal yang dapat menodai kemymiaan tauhid dan kemuliaan kegiatan ritual tersebut.

Ketiga, mengembangkan dan mengintegrasikan ke dalam bangunan pemikiran hukum Islam berbagai disiplin ilmu yang dapat mendukung analisis dalam pengembangan pemikiran hukum Islam sesuai dengan tema-tema yang diperlukan. Misalnya kajian sejarah diperlukan untuk menemukan makna dan pesan sosiomoral yang tepat mengenai praktik poligami di mạsa Rasul. Sosiologi diperlukan untuk mengkaji tingkat akseptabilitas masyarakat terhadap rencana penerapan peraturan hukum pidana perzinaan, pencurian dan penggunaan narkotika, Demikian pula penjelasan sains dan ilmu kedokteran modern amat bermanfaat untuk menkaji masalah pola waktju siklus haid wanita dan penentuan garis kęturunan (nasab).

\section{F. Penutup :}

Sekalipun harus menghadapi kritikkritik tajam dari berbagai kalangan, pola pikir kontekstùal-kultural memiliki landasan paradigmatik yang kokoh, baik dari perspektif keagamaan maupun sosial. Karakteristiknya yang moderat, terangbenderang tanpa diselimuti selubung ideologis serta releyansinya dengan denyut perkembangan kehidupan masyarakat dan sains modem menjadikannya kokoh secara konseptual. Sifat-sifatnya yang demikian menjadikan pola pemikiran tersebut terus mendapatkan banyàk dukungan dari umat dan kalangan intelektual dari generasi ke generasi.

Namun demikian, suatu ikhtiar rekonstruksi dan pengembangan konsep secara lebih komprehesif amat penting untuk dilakukan dẹmi lebih mematangkan lagi teori ini, mengatasi berbagai kelemahan yang masih ada, membangkitkan.: it kembali spirit transformatifnya yang otentik, sekaligus merespons kritik kritik dari berbagai kaḷangan yang menentangnya. Ikhtiar tersebut mencakup upaya-upaya penguatan visi sosiomoral fundamental hukum Islam secara keseluruhan maupun pada bidangbidang ttertentu; pengembangan konsep metode istinbat yañg lebih komprehensif, sistematis, dan detail, serta integrasi ilmu pengetahuan dan sains modern ke dalam bangunan pemikiraṇ hukum Islam. 
${ }^{1}$ Istilah Islam Kultural yang dimaksudkan di sini bukanlah merupakan nama suatu aliran, mazhab atau kelompok komunitas muslim tertentu, melainkan lebih menggambarkan karakter dari pola pemahaman yang sesungguhnya juga telah dikembangkan oleh banyak ahli hukum. Berbeda dengan pemahaman Islam secara Literal yang membatasi makna setiap teks syariat berdasarkan makna harfiahnya, Islam kultural justru melihat teks syariat berdasarkan arah pesan dan tujuan moralnya yang lebih fundamental sehingga lingkup makna yang dipahami melampaui batas makna harfiahnya.

${ }^{2}$ Dalam hal ini para penulis buku menggunakan istilah-istilah yang bervariasi, seperti Islam aktual, Islam Kultural, Islam Modern, Islam Rasional, dan sebagainya. Demikian pula dalam penamaan Fikih yang mereka kembangkan, ada Fikih Sosial, Fikih Aktual, Fikih Transformatif, Fikih Kontekstual dan sebagainya.

${ }^{3}$ Asghar Ali Engineer dalam Islam dan Pembebasan (Yogyakarta: LkiS, 1993), hlm. 26.

${ }^{4} \mathrm{QS}$. Al-Anfāl (8): 60.

${ }^{5}$ QS. Al-Tawbah (9): 60.

${ }^{6} \mathrm{QS}$. Al-Māidah (5) :38.

${ }^{7}$ Penjelasan luas mengenai argumen Umar atas kebijakannya ini, lihat Amiur Nuruddin, Ijtihad Umar bin Khaththab Studi tentang Perubahan dalam Hukum Islam. (Jakarta: Rajawali Press, 1991), 137-166. Mengenai kebijakan lainnya, lihat juga Munawir Syadzali, Ijtihad Kemanusiaan (Jakarta: Paramadina, 1997), hlm. 37-43.

${ }^{8}$ Ahmad Amin, Duhạa al-Islām (Kairo: Maktabah al-Nahḍah al-Mișriyyah, t.t.), II: 238.

${ }^{9}$ QS. Al-Anbiyā (21): 106.

${ }^{10}$ QS. Al-Mu'minūn (23): 1-2.

${ }^{11}$ QS. Al-Syams (91): 9-10.

${ }^{12} \mathrm{QS}$. Al-Baqarah (2): 155-157.

${ }^{13}$ QS. Al-Nahl (16): 90.

${ }^{14}$ QS. Ghāfir (40): 28.

${ }^{15} \mathrm{QS}$. Al-Hujurāt (49): 10.

${ }^{16}$ QS. Al-Mā'ūn (107): 1-5.

${ }^{17}$ Lihar juga Zaynab Riḍwān, AlNazariyyah al-Ijtimā'iyyah fí al-Fikr al-Islāmī, (Kairo: Dār al-Ma'ārif, 1982), hlm. 252-266.

${ }^{18}$ Ahmad Chatib, Hukum Islam dan Perubahan Masyarakat (Jakarta: Intermasa, 1980), 357-371. Lihat juga Yusuf Qaradawi, Ijtihad Kontemporer Kode Etika dan Berbagai Penyimpangannya, terj. Abu Barzani (Surabaya: Risalah Gusti, 1995), hlm. 7-10.

${ }^{19}$ Kaidah-kaidah interpretasi ini dikenal dengan istilah Uşül al-fiqh. Deskripsi luas mengenai teori-teori interpretasi hukum dalam Islam, lihat al-Yasa Abu Bakar, "Beberapa Teori Penalaran Fikih dan Penerapannya" dalam Tjun Sardjarman(ed.), Hukum Islam di Indonesia
Pemikiran dan Praktek (Bandung: Rosdakarya, 1994), hlm. 173- 208; Muhammad Hashim Kamali, Prinsip dan Teori-teori Hukum Islam, terj Noorhaidi (Yogyakarta: Pustaka Pelajar, 1996), khususnya Bab IV dan V (109-188).

${ }^{20}$ QS. Āli Imrān (3): 19, 85, Al-Nisā (4): 125; Al-Mā'idah (5): 3. Sebagai kajian pembanding $\mathrm{m}$,engeai prinsip-prinsip ini lihat pula Muhammad Sa'id al-Asymawi, Nalar Kritis Syariah, terj. Luthfi Thomafi (Yogyakarta: LkiS, 2004), hlm. $41-90$.

${ }^{21} \mathrm{QS}$. Al-Mā'idah (5): 44, 45, 47.

${ }^{22}$ QS. Al-Tahrīm (66) : 6.

${ }^{23} \mathrm{QS}$. Al-Mā'idah (5): 35.

${ }^{24} \mathrm{QS}$. Al-Mu'minūn (23): 1-2.

${ }^{25}$ QS. Al-Syams (91): 9-10.

${ }^{26}$ QS. Al-Baqarah (2): 155-157.

${ }^{27} \mathrm{QS}$. Al-Nahl (16): 90.

${ }^{28}$ QS. Ghāfir (40): 28.

${ }^{29} \mathrm{QS}$. Al-Hujurāt (49): 10.

${ }^{30} \mathrm{QS}$. Al-Mā'ūn (107): 1-5.

${ }^{31}$ Istilah asbāb al-nuzūl biasanya dimaknai sebagai peristiwa atau kejadian tertentu yang medorong munculnya suatu teks-teks syariat (alnusūs al-syar'iyyah) namun pemaknaan seperti itu seringkali tidak memadai untuk menangkap dengan baik pesan sosiomoral yang terkandung dalam suatui teks. Oleh karena itu istilah asbāb al-nuzūl sebaiknya dimaknai sebagai konteks sosio-hitoris dalam pengertiannya yang lebih luas serta permasalahan sosial yang kemudian direspons dengan munculnya suatu teks syariat.

${ }^{32}$ Penjelasan luas mengenai kelemahan ini lihat Kazuo Shimogaki, Islam Kiri: antara Islam Modernisme dan Post-modernisme Telaah Kritis atas Pemikiran Hassan Hanafi (Yogyakarta: LkiS, 1993), hlm. 119-121. Dalam edisi ini tulisan Hassan Hanafi yang membahas masalah ini dimuat secara lengkap di bagian belakang.

${ }^{33}$ Miftahul Huda, "Pemikiran Fikih dan Spirit Transformasi Sosial" dalam Jurnal Ulumuna edisi Juni 2009, hlm. 1-22; Lihat pula karyanya yang lain "Syariah, Fikih dan Sebuah Perspektif tentang Tarjih" dalam Islamica: Jurnal Studi Keislaman, 5, 2 (2011), hlm. 220-233.

$$
{ }^{34} \text { Muhammad Zainul Majdi, }
$$

"Kesempurnaan Syariat Islam dan Probabilitas Penerapan" alam Jurnal Ulumuna, 5, 1 (2003), hlm. 1-11.

${ }^{35}$ Hasanain Juaini, "Menakar Islam Sebagai Alternatif Di Tengah Ironi dan Ambiguitas Demokrasi Global" dalam Jurnal Ulumuna, 5, 1 (2003), hlm. 47-60.

${ }^{36}$ Rahman Alwi, Metode Injtihad Mazhab Zhahiri Alternatif Menyongsong Modernitas (Jakarta: Gaung Persada Press, 2005), hlm. 31-71. 
${ }^{37}$ Akh. Minhaji, "Ushul Fikih dan Perubahan Sosial dalam Perspektif Sejarah" dalam Amin Abdullah dkk. Mencari Islam: Studi Islam dengan Berbagai Pendekatan. (Yogyakarta: Tiara Wacana Yogja, 2000), hlm. 73-74.

${ }^{38}$ Lihat pula John L Esposito, Islam Warna-warni Regam Ekspresi Menuju' "Jalan Lurus", terj. Arif Maftuhin (Jakarta: Paramadina, 2004), hlm. 278-311.

${ }^{39}$ QS. Äli Imrān (3) : 19, 85, Al-Nisä (4):

125; Al-Mā'idah (5): 3.

${ }^{40} \mathrm{QS}$. Al-Tahrïm (66): 6.

${ }^{41}$ QS. Al-Mā'idah (5): 35.

${ }^{42}$ QS. Al-Mā'idah (5): 44, 45, 47.

${ }^{43} \mathrm{QS}$. Al-Tawbah (11): 60.

\section{DAFTAR PUSTAKA}

Abu Bakar, Alyasa. "Beberapa Teori Penalaran Fikih dan Penerapannya". dalam Tjun Sudjarman (ed.). Hukum Islam di Indonesia Pemikiran dan Praktek. Bandung: Rosdakarya, 1994.

Alwi, Rahman. Metode Ijtihad Mazhab Zhahiri Alternatif Menyongsong Modernitas. Jakarta: Gaung Persada Press, 2005

Amin, Ahmad. Duthā al-Islām. Kairo: Maktabah al-Nahḍah al-Mișriyyah, t.t.

Al-Asymawi, Muhammad Sa'id. Nalar Kritis Syariah. terj. Luthfi Thomafi. Yogyakarta: LkiS, 2004.

Chatib, Ahmad. Hukum Islam dan Perubahan Masyarakat. Jakarta: Intermasa, 1980.

Engineer, Asghar Ali. Islam dan Pembebasan. Yogyakarta: LkiS, 1993.

Esposito, John L. Islam Warna-warni Regam Ekspresi Menuju "Jalan Lurus", terj. Arif Maftuhin. Jakarta: Paramadina, 2004.
Huda, Miftahul. "Pemikiran Fikih dan Spirit Transformasi Sosial." Dalam Jurnal Ulumuna, edisi Juni 2009.

Juaini, Hasanain "Menakar Islam Sebagai Alternatiff Di Tengah Ironi dan Ambiguitás . Demokrasi Global". Dalam Jurnal Ulumuna, 5, 1 (2003).

Kamali, Muhammad Hashim. Prinsip dan Teori-teori Hukum Islam. terj Noorhaidi. Yogyakarta: Pustaka Pelajar, 1996.

Majdi, Muhammad Zainul. "Kesempứmaan Syariat Islam dan Probabilitas Penerapan". Dalam Jurnal Ulumuna, 5, 1, (2003)

Minhaji, Akh. "Ushul Fikih dan Perubahan Sosial dảlam Perspektif Sejarah" dalam . Ámin Abdullah dkk. Mencari Islam: Studi Islam dengan Berbagai Pendekatan. Yogyakarta: Tiara Waçana Yogja, 2000.

Nuruddin, Amiur. Ijtihad Umar bin Khaththab' Studi tentang Perubahan dalam Hukum Islam. Jakarta: Rajawali Press, 1991.

Qaradhawi, Yusúf. Ijtihad Kontemporer Kode 'Etika dan Berbagai Penyimpangannya. terj. Abu Barzani. Șurabaya: Risalah Gusti, 1995.

Riḍwan, Zainab. Al-Nazariyyah alIjtimā'iyyáh $f i$ al-Fikr al-Islämi. Kairo: Dar al-Ma'arif, 1982.

Shimogaki, Kazuo. Kiri Islam: Antara Islam Modernisme dan Postmodernisme Telaah Kritis atas Pemikirani Hassan Hanafi. Yogyakarta: LkiS, 1993.

Sjadzali, Munawir. Ijtihad Kemanusiaan. Jakarta: 'Päramadina, 1997.

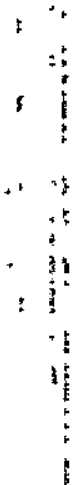

